\title{
Fat Cell Metabolism in Different Regions in Women Effect of Menstrual Cycle, Pregnancy, and Lactation
}

Marielle Rebuffé-Scrive, Lennart Enk, Nils Crona, Peter Lönnroth, Lars Abrahamsson, Uif Smith, and Per Björntorp Clinical Metabolic Laboratory of the Department of Medicine I, Departments of Medicine II and Obstetrics and Gynecology, Sahlgren's Hospital, University of Göteborg, Sweden

\begin{abstract}
Adipose tissue lipolysis and lipoprotein lipase (LPL) activity were studied in biopsies from the femoral and abdominal depots in healthy women during early or late menstrual cycle, pregnancy, and the lactation period.

When the differences in cell size were taken into account, basal lipolysis was similar in both regions in nonpregnant women. During lactation, however, lipolysis was significantly higher in the femoral region. The lipolytic effect of noradrenaline $\left(10^{-6} \mathrm{M}\right)$ was significantly less in the femoral region in the nonpregnant women and during early pregnancy. However, the lipolytic response was the same in both regions in lactating women. LPL activity was higher in the femoral than in the abdominal region except during lactation when a marked decrease in the LPL activity was seen in the femoral region. The LPL activity in the abdominal region remained unchanged in all patient groups.

The results imply that in both nonpregnant and pregnant women lipid assimilation is favored in the femoral depot. During lactation, however, the metabolic pattern changes; the LPL activity decreases and lipid mobilization increases in this depot. These changes are much less pronounced in the abdominal region. Thus, fat cells from different regions show a differential response during pregnancy and lactation. These results suggest that the adipose tissue in different regions may have specialized functions.
\end{abstract}

\section{Introduction}

It has long been recognized that the subcutaneous adipose tissue shows a characteristic regional distribution in men and women (1-3). Women, for instance, have a predominance of the gluteal and femoral regions while, in men, the abdominal region has the largest adipose tissue thickness. This characteristic distribution is maintained even in grossly obese individuals (3).

Recent studies have demonstrated metabolic differences, both quantitative and qualitative, between adipocytes in various regions. For instance, the lipolytic response to catecholamines is considerably smaller in adipocytes from the femoral than

These data were presented in part at the IVth International Congress on Obesity, New York, 1983.

Dr. Rebuffé-Scrive's present address is Service de Medicine et Nutrition, Hotel Dieu, Paris, France.

Received for publication 16 July 1984 and in revised form 6 February 1985.

J. Clin. Invest.

(c) The American Society for Clinical Investigation, Inc. 0021-9738/85/06/1973/04 \$1.00

Volume 75, June 1985, 1973-1976 from the abdominal region (4-6). The lipoprotein lipase (LPL) ${ }^{1}$ activity shows an inverse relationship with the lipolytic responsiveness, i.e., higher LPL activity in the femoral than in the abdominal region $(7,8)$.

Studies in the experimental animal have shown marked changes in fat cell metabolism during pregnancy and lactation. Fat cell LPL activity in the parametrial depot is increased during pregnancy while a reduction occurs during lactation when the mammary gland LPL becomes markedly increased (9). Prolactin may exert an important regulatory effect on the LPL activity in these sites (10). Recent studies by Steingrimsdottir et al. (11) suggest that this inverse regulation in adipose and mammary gland LPL activity during pregnancy and lactation in the rat is not a uniform response but specific to certain adipose regions.

As discussed above, women have more fat and larger fat cells than men in the femoral region. One reason for this particular accumulation of adipose tissue in women could be that the femoral region subserves a specific function. To test this hypothesis, lipolysis and LPL activity were examined in adipocytes from the femoral and abdominal regions in women during the menstrual cycle, pregnancy, and lactation. The results clearly show that the femoral fat cells change their metabolic pattern and become lipolytic during lactation, supporting the concept of a specialized function.

\section{Methods}

\section{Patients}

Control group. For the studies on fat cell metabolism during the menstrual cycle, healthy women, 30-40-yr-old, were recruited. They all had a regular menstrual cycle, did not take any contraceptive pills, and were not obese. 12 women who had progesterone levels above 10 nmol/liter at day 24-25 of the menstrual cycle, indicating that they had ovulated, were selected for the study. They were examined both during days $10-12$ and days 24-25 of their menstrual cycle. Their clinical characteristics are shown in Table I. 10 of these women had given birth to children and had then lactated for at least 3 mo.

Pregnancy. 13 women undergoing legal abortion were studied. They were 25-42-yr-old and nonobese. The length of gestation was between 8 and 11 wk. They did not adhere to a particular diet. One woman vomited during the first week of pregnancy and two women felt that they ate more while three ate less than normal. The remaining eight felt well and reported unchanged eating habits during the pregnancy. The characteristics of these women are also shown in Table I.

Lactation. This group of nine volunteers was selected from women who breast-fed their babies. The clinical characteristics are shown in Table I. All women were studied during lactation $1 \mathrm{mo}$ after delivery. None had a history of gestational diabetes or diabetes in the family. Repeated monitoring of glucosuria during late pregnancy was negative.

All procedures were explained in detail to the participants before

1. Abbreviation used in this paper: LPL, lipoprotein lipase. 
they gave their consent. The study was approved by the Ethical Committe of the University of Göteborg.

\section{Experimental procedures}

The patients were studied in the morning after an overnight's fast. A venous blood sample was taken for glucose, triglyceride, insulin, and steroid hormone determinations at the same time as the adipose tissue biopsy was taken. A needle biopsy ( $\sim 300 \mathrm{mg}$ ) was obtained from the subcutaneous tissue in the femoral (just below the femoral trochanter) and the abdominal (lateral to the umbilicus) regions.

The adipose tissue samples were used for LPL determinations following homogenization and acetone-ether extraction according to the method described by Nilsson-Ehle et al. (12). Lipolytic measurements were performed on cells isolated from the stroma by incubating the fragments in medium 199 containing 4\% (wt/vol) albumin and 1.5 $\mathrm{mg} / \mathrm{ml}$ collagenase (Sigma Chemical Co., St. Louis, MO) for $60 \mathrm{~min}$ at $37^{\circ} \mathrm{C}$, as previously described (13). After filtration through a nylon mesh $(250 \mu \mathrm{m})$, the cells were carefully washed four times and suspended in fresh medium. 100- $\mu$ l aliquots from the cell suspension, lipocrit $20-25 \%$, were added to siliconized bottles containing $2 \mathrm{ml}$ medium 199 with $4 \%$ albumin with or without $10^{-6} \mathrm{M}$ noradrenaline (Sigma Chemical Co.) as indicated. Control experiments have shown that under these incubation conditions with a low lipocrit (1-2\%), glycerol release remains linear for at least $3 \mathrm{~h}$. After 2-h incubation at $37^{\circ} \mathrm{C}$ and $\mathrm{pH} 7.4$, cells and medium were transferred to soft plastic tubes and centrifuged through silicone oil to separate the cells and the incubation medium as described by Gammeltoft and Gliemann (14). The glycerol content of the medium was analyzed enzymatically (15) and was taken as an index of lipolysis. The fat cell triglycerides were extracted according to Dole et al. (16) and determined as described by Carlson (17). The size of the isolated cells was measured according to Smith et al. (13). Mean fat cell surface area (SA) was calculated according to the formula: $\mathrm{SA}=\pi\left(d^{2}+\mathrm{SD}^{2}\right)$, where $d$ equals mean fat cell diameter.

Blood glucose was determined with glucose oxidase (GLOX; Kabi, Stockholm, Sweden), plasma triglycerides by an enzymatic method (Boehringer, Ingelheim, Federal Republic of Germany), and insulin by a radioimmunoassay (Phadebas; Pharmacia, Uppsala, Sweden). Progesterone, prolactin, and 17- $\beta$-estradiol were determined according to the routine methods of the hospital (kindly performed by Dr. Göran Lindstedt, Dept. of Clinical Chemistry).

\section{Statistical methods}

Wilcoxon's signed rank sum test was utilized for comparisons between matched pairs and the Mann-Whitney $U$ test for unpaired data. Correlation coefficients were tested with Spearman's rank method.

\section{Results}

\section{Patient characteristics}

The women examined during lactation were somewhat younger than the controls. Otherwise there were no significant differences between the groups (Table I).

Fat cells in the femoral region were larger than those in the abdominal region in all groups (Table II). Furthermore, the fat cells in both the abdominal and femoral regions were larger in the lactating women than in the controls (Table II). The progesterone levels were higher late in the menstrual cycle in the control subjects and in the pregnant women. 17- $\beta$ estradiol was also elevated during pregnancy while the prolactin levels were high both during pregnancy and lactation (Table II).

\section{Adipose tissue metabolism}

Lipolysis. Initial experiments were carried out to characterize the dose-response curve to catecholamines. A maximal response
Table I. Clinical Characteristics of Subjects

\begin{tabular}{lccc}
\hline & $\begin{array}{l}\text { Controls } \\
(n=12)\end{array}$ & $\begin{array}{l}\text { Pregnant } \\
(n=13)\end{array}$ & $\begin{array}{l}\text { Lactating } \\
(n=9)\end{array}$ \\
\hline Age $(y r)$ & $36.7 \pm 0.9$ & $33.1 \pm 2.1$ & $30.7 \pm 1.7^{*}$ \\
Height $(\mathrm{cm})$ & $169 \pm 1.9$ & $167 \pm 1.3$ & $167 \pm 2.9$ \\
Weight $(\mathrm{kg})$ & $63.5 \pm 1.7$ & $61.9 \pm 1.5$ & $68.3 \pm 4.2$ \\
$\begin{array}{l}\text { Body mass index } \neq \\
\begin{array}{c}\text { Number of previous } \\
\text { pregnancies }\end{array}\end{array}$ & $22.3 \pm 0.5$ & $22.1 \pm 0.5$ & $24.3 \pm 1.0$ \\
$\begin{array}{l}\text { Length of gestation } \\
(w k)\end{array}$ & $1.6 \pm 0.2$ & & $1.9 \pm 0.4$ \\
\hline
\end{tabular}

Results are means \pm SEM.

* $P<0.05$ compared with the control group. $\ddagger$ Weight $(\mathrm{kg}) /$ height $\left(\mathrm{m}^{2}\right)$.

was seen with $10^{-5} \mathrm{M}$ noradrenaline (not shown) in agreement with other studies (4-6). In the subsequent experiments, $10^{-6}$ $M$ noradrenaline was routinely used to evaluate both sensitivity and responsiveness.

Basal lipolysis of the femoral and abdominal fat cells of the different patient groups is shown in Fig. $1 a$. These results are expressed per unit surface area to correct for the differences in cell size (cf. Table II). The glycerol release was similar in the fat cells of the abdominal region in the pregnant and the control groups but tended to increase in the lactating patients. Lipolysis in the femoral cells tended to increase in both the pregnant and the lactating groups (Fig. $1 a$ ). The lipolytic rate was not significantly different between the two regions except during lactation when lipolysis was significantly higher in the femoral region. Thus, when compared with the control groups, basal lipolysis increased to a greater extent in the femoral than in the abdominal region during lactation.

Lipolysis in response to a submaximal noradrenaline concentration is shown in Fig. $1 \mathrm{~b}$. In both nonpregnant groups and during pregnancy, the lipolytic rate was markedly higher in the abdominal region. During lactation, however, there was no difference between the two regions (Fig. $1 b$ ). As shown in

Table II. Fat Cell Size, Hormones, and Metabolic Variables

\begin{tabular}{|c|c|c|c|c|}
\hline & \multicolumn{2}{|c|}{ Controls $(n=12)$} & \multirow{2}{*}{$\begin{array}{l}\text { Pregnancy } \\
(n=13)\end{array}$} & \multirow{2}{*}{$\begin{array}{l}\text { Lactation } \\
(n=9)\end{array}$} \\
\hline & Day $10-12$ & Day 24-25 & & \\
\hline $\begin{array}{l}\text { Abdominal fat cell } \\
\text { size }(\mu g)\end{array}$ & $0.32 \pm 0.04$ & $0.32 \pm 0.04$ & $0.35 \pm 0.02$ & $0.54 \pm 0.06$ \\
\hline $\begin{array}{l}\text { Femoral fat cell } \\
\text { size }(\mu g)\end{array}$ & $0.48 \pm 0.05$ & $0.47 \pm 0.04$ & $0.46 \pm 0.03$ & $0.74 \pm 0.09$ \\
\hline $\begin{array}{l}\text { Glucose } \\
\text { (mmol/liter) }\end{array}$ & $3.9 \pm 0.09$ & $4.4 \pm 0.14$ & $3.8 \pm 0.1$ & $3.7 \pm 0.02$ \\
\hline $\begin{array}{l}\text { Insulin } \\
\quad \text { (mU/liter) }\end{array}$ & $7 \pm 1$ & $6 \pm 1$ & $4 \pm 1$ & $8 \pm 1$ \\
\hline $\begin{array}{l}\text { Triglycerides } \\
(\mathrm{mmol} / \mathrm{liter})\end{array}$ & $0.60 \pm 0.05$ & $0.57 \pm 0.06$ & $0.62 \pm 0.07$ & $1.07 \pm 0.14$ \\
\hline $\begin{array}{l}\text { Progesterone } \\
\text { (nmol/liter) }\end{array}$ & $1 \pm 0$ & $40 \pm 7$ & $76 \pm 8$ & $1 \pm 0$ \\
\hline $\begin{array}{r}\text { 17- } \beta \text {-estradiol } \\
(\text { nmol/liter })\end{array}$ & $0.49 \pm 0.16$ & $0.65 \pm 0.02$ & $2.4 \pm 0.4$ & $0.18 \pm 0.04$ \\
\hline $\begin{array}{l}\text { Prolactin } \\
(\mu \mathrm{g} / \text { liter })\end{array}$ & $19 \pm 2$ & $20 \pm 3$ & $76 \pm 8$ & $101 \pm 15$ \\
\hline
\end{tabular}


a

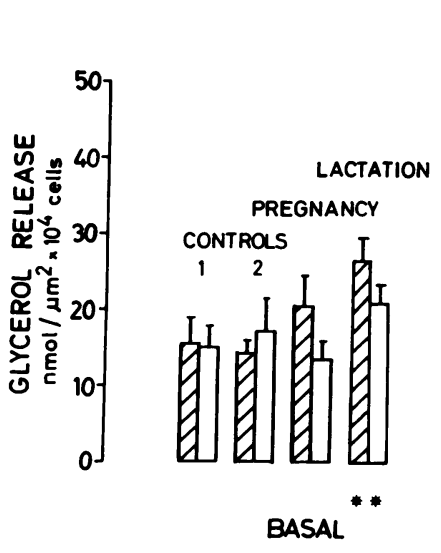

b

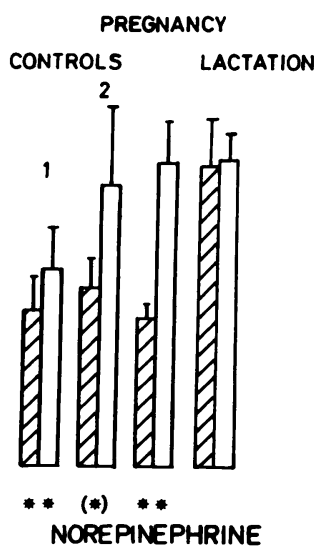

Figure 1. Glycerol release from adipocytes of the femoral (hatched bars) and the abdominal (open bars) regions without (a-left) or with (b-right) the addition of $10^{-6} \mathrm{M}$ noradrenaline to the incubation medium. The incubations were performed for $2 \mathrm{~h}$. The results are the means \pm SEM and are expressed per unit surface area to correct for the differences in cell size. ${ }^{*} P<0.10,{ }^{* *} P<0.01$ comparing femoral and abdominal regions.

Fig. 2, the absolute response to catecholamine, calculated by subtracting basal lipolysis, was markedly higher in abdominal than in femoral adipocytes in the nonpregnant groups and, in particular, during pregnancy. The femoral cells were virtually totally unresponsive to catecholamine in the pregnant group (Fig. 2). During lactation, however, both regions were equally responsive to noradrenaline. Thus, changes in the lipolytic effect of catecholamine were seen in both regions but they were more pronounced in the femoral region.

The results in Figs. 1 and 2 are expressed per unit cell surface area to compensate for the differences in cell size. However, the same results were obtained even when the data were calculated per cell number (data not shown).

LPL activity. The femoral region exhibited significantly higher LPL activity than the abdominal region in all groups except during lactation (Fig. 3). This difference was particularly pronounced during pregnancy. The LPL activity in the abdominal region remained unchanged in all patient groups. However, the high LPL activity in the femoral region during pregnancy was markedly reduced during lactation $(P<0.05$, Fig. 3$)$. The sum of the LPL activity in the two regions was less in lactating women than in the other patients groups $(P<0.05$, not

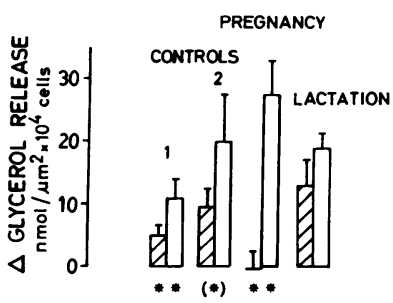

Figure 2. The absolute increase of glycerol release induced by $10^{-6} \mathrm{M}$ noradrenaline (glycerol release in the presence of noradrenaline minus basal glycerol release) in the femoral (hatched bars) and the abdominal (open bars) region. The incubations were performed for 2 h. The results are the

means \pm SEM and are expressed per unit cell surface area to correct for the differences in cell size. ${ }^{*} P<0.10,{ }^{* *} P<0.01$ comparing femoral and abdominal regions.

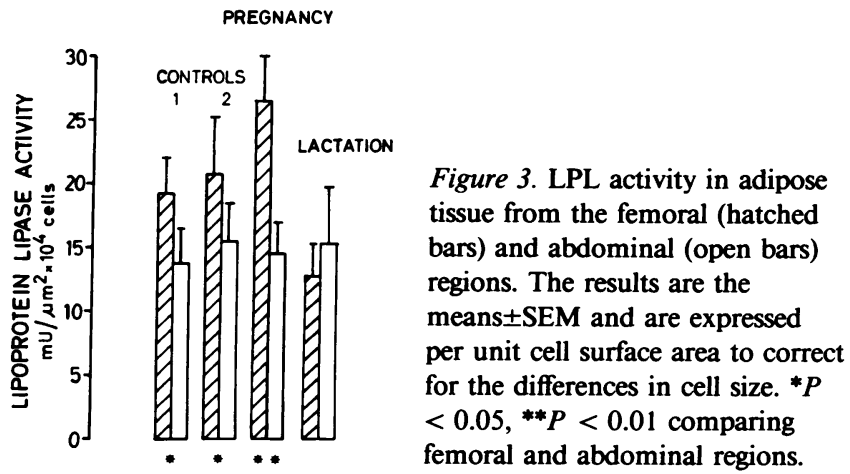

shown). The results in Fig. 3 are expressed per unit surface area. However, the same findings were obtained even if the results are calculated per cell number (data not shown).

\section{Discussion}

The present study was designed to elucidate the lipid mobilization and assimilation processes in women during the menstrual cycle, pregnancy, and lactation. Since a longitudinal study was obviously impossible, the subjects had to be matched as closely as possible. The pregnant and lactating groups were slightly younger than the controls but the differences were small. It was also impossible to have a strict control of the diet. These shortcomings, due to the particular nature of the study, may have some influence on the quantitative differences between the groups but not on the pattern of response seen in the two regions.

Adipocyte metabolism is a function of the size of the fat cells (for review, see ref. 18). The influence of this factor can be eliminated by expressing the results per unit cell surface area (18) and this was performed in the present study. However, the same differences between the groups and regions were found even when the data were expressed per number of cells. Thus, differences in cell size can not explain the perturbations in fat cell metabolism associated with pregnancy and lactation.

The hormone analyses were performed to identify the phases of the menstrual cycle when the biopsies were performed, i.e., late follicular and late luteal phase. The hormonal changes were also those expected for an early (9-10 wk) pregnancy and the lactating period.

Basal lipolysis increased during lactation in the femoral region. The lipolytic effect of a submaximal noradrenaline concentration was also clearly different in the two regions. In the nonpregnant groups and during pregnancy, lipolysis was considerably higher in the abdominal than in the femoral fat cells. Similar results have previously been repeatedly reported in nonpregnant individuals and, in part, attributed to an increased $\alpha$-receptor-mediated inhibition of lipolysis (4-6). During lactation, however, there was no difference in lipolytic rate between the regions. This was due to both the increased basal lipolysis and to an improvement of the catecholamine responsiveness in the femoral region.

LPL activity in the abdominal region remained unchanged in all groups. In the femoral region, however, marked differences were seen. The higher LPL activity in the femoral than in the abdominal region during the menstrual cycle was even further 
accentuated during pregnancy. During lactation, however, a marked decrease in LPL activity was seen in the femoral region. A similar pattern has previously been described in adipose tissue from rats (9-11). The decreased LPL activity in the parametrial depot during lactation is associated with an increased LPL activity in the mammary gland (9). The decreased femoral and total (abdominal plus femoral) adipose LPL activity in lactating women is likely to have been associated with an increased LPL activity in the mammary gland, although a direct demonstration of this was not possible in the present study.

The changes in adipocyte metabolism in the two regions examined are probably associated with the variations in the levels of the sex hormones. Statistically significant positive correlations were also found between the $17-\beta$-estradiol levels and lipolysis in the control groups and the pregnant women (data not shown).

When the changes in the metabolic parameters representing lipid assimilation and mobilization are considered together, the following integrated scheme appears reasonable. During the menstrual cycle, LPL activity is elevated and lipid mobilization low in the femoral adipocytes. This may lead to the accumulation of triglycerides in the femoral depot producing larger fat cells, which was also found in the present report, and has previously been reported in young (2), middle-aged (19), and obese (3) women. This metabolic pattern is accentuated during pregnancy when the LPL activity is even further elevated and lipolysis in the femoral region impaired. However, the metabolic pattern changes during lactation. Lipid mobilization is increased and lipid accumulation, measured as LPL activity, decreased. Thus, the previous pattern favoring triglyceride accumulation in the femoral adipocytes in nonpregnant and pregnant women becomes changed so that this depot can apparently be effectively utilized. Although some changes occur in the abdominal cells, the most marked changes are seen in the femoral cells. Thus, it is possible that the femoral adipose tissue may serve a specialized function in women, i.e., it is utilized as an important source of energy supply during lactation. This possibility is also supported by the characteristic preponderance of the femoral depots in women and by the fact that men usually only have a small femoral depot $(2,3)$.

Obesity in the lower part of the body is less closely associated with the various metabolic complications of obesity as compared with the abdominal type $(1,3,20)$. The metabolic differences between these depots provide a functional basis for these findings and also offer a likely explanation to the observation that the femoral-gluteal fat is difficult to reduce during caloric restriction in obese women (21).

\section{Acknowledgments}

The technical assistance by Ulla Carlbrand, Monica Hansson, and Britt-Marie Larsson is gratefully acknowledged.

Dr. Rebuffe-Scrive is a research fellow in the INSERM-Swedish Medical Research Council Exchange Program. This study was supported by grants from the Swedish Medical Research Council (projects B8403X-03506-13C, B83-19F-6419-01 and B83-19X-251-21A) and INSERM, France.

\section{References}

1. Vague, J. 1947. La différenciation sexuelle-facteur determinant des formes de l'obésité. La Presse Médicale 30:339-340.

2. Sjöström, L., U. Smith, M. Krotkiewski, and P. Björntorp. 1972. Cellularity in different regions of adipose tissue in young men and women. Metab. Clin. Exp. 21:1143-1153.

3. Krotkiewski, M., P. Björntorp, L. Sjöström, and U. Smith. 1983. Impact of obesity on metabolism in men and women. Importance of regional adipose tissue distribution. J. Clin. Invest. 72:1150-1162.

4. Kather, H., F. Schröder, B. Simon, and G. Schlierf. 1977. Human fat cell adenylate cyclase: regional differences in hormone sensitivity. Eur. J. Clin. Invest. 7:595-597.

5. La Fontan, M., L. Dang-Tran, and M. Berlan. 1978. Alphaadrenergic antilipolytic effect of adrenaline in human fat cells of the thigh: comparison with adrenaline responsiveness of different fat deposits. Eur. J. Clin. Invest. 9:261-266.

6. Smith, U., J. Hammarsten, P. Björntorp, and J. Kral. 1979. Regional differences and effect of weight reduction on human fat cell metabolism. Eur. J. Clin. Invest. 9:327-332.

7. Lithell, H., and J. Boberg. 1978. The lipoprotein-lipase activity of adipose tissue from different sites in obese women and the relationship to the cell size. Int. J. Obesity. 2:47-52.

8. Guy-Grand, B., and M. Rebuffe-Scrive. 1980. Anatomical and nutritional correlates of lipoprotein lipase of human adipose tissue. Proc. 3rd Int. Congr. Obesity. 273.

9. Hamosh, M., T. R. Clary, S. S. Chernick, and R. O. Scow. 1970. Lipoprotein lipase activity of adipose and mammary tissue and plasma triglyceride in pregnant and lactating rats. Biochim. Biophys. Acta. 210:473-482.

10. Zinder, D., M. Hamosh, T. R. C. Fleck, and R. O. Scow. 1974. Effect of prolactin on lipoprotein lipase in mammary glands and adipose tissue of rats. Am. J. Physiol. 226:742-748.

11. Steingrimsdottir, L., M. R. C. Greenwood, and J. A. Brasel. 1980. Effect of pregnancy, lactation and a high-fat diet on adipose tissue in Osborne-Mendel rats. J. Nutr. 110:600-609.

12. Nilsson-Ehle, P., H. Tornqvist, and P. Belfrage. 1972. Rapid determination of lipoprotein lipase activity in human adipose tissue. Clin. Chim. Acta. 42:383-390.

13. Smith, U., L. Sjöström, and P. Björntorp. 1972. Comparison of two methods of determining human adipose cell size. J. Lipid. Res. 13:822-824.

14. Gammeltoft, S., and J. Gliemann. 1973. Binding and degradation of ${ }^{125}$ I-insulin by isolated rat fat cells. Biochim. Biophys. Acta. 320:1632.

15. Laurell, S., and S. Tibbling. 1966. An enzymatic micromethod for the determination of glycerol. Clin. Chim. Acta. 13:317-322.

16. Dole, V. P., and H. Meinertz. 1960. Microdetermination of long-chain fatty acids in plasma and tissues. J. Biol. Chem. 235:25952599.

17. Carlson, L. A. 1959. Determination of serum glycerides. Acta. Soc. Med. Ups. 64:208-213.

18. Björntorp, P., and U. Smith. 1976. The effect of fat cell size on subcutaneous adipose tissue metabolism. Front. Matrix. Biol. 2: $37-61$.

19. Krotkiewski, M., L. Sjöström, P. Björntorp, and U. Smith. 1975. Regional adipose tissue cellularity in relation to metabolism in young and middle-aged women. Metab. Clin. Exp. 24:703-710.

20. Kissebah, A. H., N. Vydelingum, R. Murray, D. J. Evans, A. J. Hartz, R. K. Kalkhoff, and P. W. Adams. 1982. Relation of body fat distribution to metabolic complications of obesity. J. Clin. Endocrin. Metab. 54:254-260.

21. Björntorp, P. 1984. Adipose tissues in obesity. Proc. IVth Int. Congr. Obesity. In press. 